\title{
Strategy as a response to organizational uncertainty: an alternative perspective on the strategy-performance relationship
}

Parnell, John A; Lester, Donald L; Menefee, Michael L. Management Decision ; London Vol. 38, Iss. 8, (2000): 520-530.

PProQuest document link

\section{ABSTRACT}

Much of the literature suggests that strategies are formulated in light of perceived environment conditions and internal capabilities. This study supports the notion that strategy is formulated in part as a response to management uncertainties about competitors, customers, and the environment. Responses from 137 wholesale grocers demonstrate that uncertainty varies by generic strategy, suggesting that business consider both the type and degree of uncertainty when crafting a competitive strategy.

\section{FULL TEXT}

John A. Parnell: Department of Marketing \&Management, Texas A\&M University-Commerce, Texas, USA Donald L. Lester: McAfee School of Business Administration, Union University, Jackson, Tennessee, USA Michael L. Menefee: Organizational Leadership \&Supervision, Purdue University, West Lafayette, Indiana, USA The literature is replete with empirical tests of the strategy-performance relationship. Indeed, much of the current research continues to develop theory and empirically test models based on the notion that strategy should "fit" with a variety of organizational and environmental constructs in order to result in superior performance (e.g. Barney, 1986; Covin, 1991; Hamilton and Shergill, 1992; Neilsen, 1992). However, few studies have considered the organizational and environmental factors that precede the adoption of a given strategy. This paper addresses one of these critical factors, asking: "Do environmental uncertainties perceived by organizational managers influence the strategies formulated and implemented at the business level?"

The remaining part of this paper is divided into five sections. Following an overview of the strategy-performance linkage, propositions are presented and methods for testing them are outlined. Findings of the investigation are then reported, followed by conclusions and directions for future research.

The strategy-performance linkage

An investigation of the relationship between perceived uncertainty and an organization's competitive strategy must follow a discussion of generic business strategies and their association with performance. Although each firm's strategy is idiosyncratic, researchers have sought to classify business strategies into typologies to study more effectively relations between strategy and other variables, including environment, structure, and performance (Namiki, 1989). Research has demonstrated the usefulness of typologies in contingency strategy research (Herbert and Deresky, 1987; Hill, 1988; Lawless and Finch, 1989).

Most researchers have utilized versions of either the typology proposed by Miles and Snow (1978) or the one proposed by Porter (1980). The former approach is theoretically built on perceptions of the environment and is applied in the present study.

The Miles and Snow typology

Miles and Snow's (1978) commonly used framework is rooted in Child's (1972) conceptualization of strategic 
choice and considers the rate at which organizations change their products or markets. Miles and Snow (1978) assume that organizations act to create their own environments through a series of choices regarding markets, products, technologies, desired scale of operations, and so on. The enacted environment is severely constrained by existing knowledge of alternative organizational forms and managers' beliefs about how people can and should be motivated (Miles and Snow, 1978).

Miles and Snow (1978) proposed that organizations develop relatively enduring patterns of strategic behavior to co-align the organization with the environment. Prospectors perceive a dynamic, uncertain environment and maintain flexibility to combat environmental change. The prospector seeks to identify and exploit new product and market opportunities. In contrast, defenders perceive the environment to be stable and certain, and thus seek stability and control in their operations to achieve maximum efficiency. Analyzers stress both stability and flexibility and attempt to capitalize on the best of both of the preceding strategic types (McKee et al., 1989). Reactors lack consistency in strategic choice and perform poorly.

One caveat to the strategy-performance relationship should be elaborated. Specifically, researchers do not agree as to whether businesses can attain superior performance by combining generic strategies. In its simplest form, the genesis of this combination strategy debate can be traced back to Porter's contention that viable business units seek either a low cost or a differentiation strategy (Dess and Davis, 1984; Hambrick, 1981, 1982; Hawes and Crittendon, 1984). However, many researchers believe that adopting a combination strategy can result in superior performance over the long run (Buzzell and Gale, 1987; Hill, 1988; Jones and Butler, 1988; Murray, 1988; Parnell et al., 1993; White, 1986; Wright, 1987; Wright et al., 1991a; 1991b).

Recent research has extended the "combination strategy" perspective both conceptually (Hurst et al., 1989) and empirically (Wright et al., 1990) to suggest that a combination strategic orientation exists without trade-offs and is associated with superior business performance. Indeed, there is increasing evidence that many, if not most, businesses combine generic strategies to some extent (Kotha et al., 1995), and that the forms of combination vary across cultures (Lemak and Arunthanes, 1997; Luo, 1997). In support of the second school, Wright et al. (1990) proposed a high-performing combination strategy - the "balancer".

The balancer organization operates in three separate product-market spheres. In one sphere, managers stress established products and buyers. The resistance in this product-market to technological change closely resembles the defender type of organization. In the second sphere - similar to the analyzer type - technological changes are welcomed only if they explicitly have yielded promising products for competitors. The efforts of the balancer in the remaining market area (i.e. the third sphere) are characterized by the initiation of technological change. Organizational processes tend to be organic, similar to those processes characteristic of the prospector type of organization.

Uncertainty, strategy, and performance

Strategic management helps organizations cope with uncertainty by shaping the competitive environment (Allaire and Firsirotu, 1989; Guth, 1976; Jauch and Kraft, 1986). The generic strategy selected by each organization determines the means by which it intends to successfully meet competitive challenges (Porter, 1980). Better information and certainty about the environment - other variables held constant - tend to translate into superior performance (Ashmore, 1992). As Thompson (1967) noted, the management of uncertainty is the primary challenge of top management.

The interpretation of uncertainty is seen clearly throughout the ranks of the organization. In contrast to Miles and Snow's original (1978) work, Hurst et al. (1989) and Wright et al. (1990) emphasized more greatly the role of multiple managers in building the superior performing organization. However, much of the strategy research in the 1970s and early 1980s followed Ansoff (1965) and others (Andrews, 1971; Schendel and Hofer, 1979), relying on perceptions of the top manager for insight into an organization's strategic intentions. Although the concept of middle management involvement in strategy is not a recent phenomenon, the last decade has produced evidence to suggest that strategy formulation and implementation can reflect a diverse array of top and middle management inputs (Barney, 1986; Burgelman, 1983; Fredrickson, 1984; Hart, 1992). Mintzberg and Waters' (1985) 
notion of deliberate and emergent strategies acknowledges the significant role of top and middle managers in the strategic management process (see also Burgelman, 1983; Hiam, 1993; Nichol, 1992; Wooldridge and Floyd, 1989, 1990).

\section{Propositions}

Considerable research has demonstrated support for the Miles and Snow (1978) typology (e.g. Conant et al., 1990; Hambrick, 1979, 1983; McDaniel and Kolari, 1987; Meyer, 1982; Ruekert and Walker, 1987; Zahra, 1987). Many notable studies conclude that superior performance can typically be found in prospectors, analyzers, and defenders, while reactors tend to perform poorly. Snow and Hrebiniak's (1980) study of 100 businesses in the plastics, semiconductor, automotive and air transportation industries demonstrated similar conclusions. Studies that have considered the fifth strategic type have found balancers to be the superior performers in selected industries (Parnell et al., 1993; Wright et al., 1990).

This study explores the Miles and Snow (1978) typology among wholesale grocers. One key measure of performance - return on assests - is adopted for the purpose of the investigation. Specifically, this study seeks to test three hypotheses.

$\mathrm{H} 1 \mathrm{a}$ : Balance businesses will experience ROAs significantly higher than those of other businesses.

$\mathrm{H} 1 \mathrm{~b}$ : Reactors will experience ROAs significantly lower than those of other businesses.

Organizations able to pursue the other three viable strategies simultaneously (i.e. the balancer strategy) should benefit from synergy and enjoy superior performance (Parnell et al., 1993; Wright et al., 1990). Organizations lacking a coherent strategy should perform poorly, just as they have in other empirical tests of the Miles and Snow (1978) typology (McKee et al., 1989; Parnell et al., 1993). Support for both parts of this proposition will suggest that industry selection and data collection techniques have produced results similar to those found in earlier studies, a necessary prerequisite for valid testing of the remaining propositions.

$\mathrm{H}$ 2: Management uncertainties about competitors, customers, and the environment will vary by generic strategy. This hypothesis suggests that the strategy construct has an uncertainty component. Specifically, a business strategy not only reflects competitive intentions, but also provides insight into how top executives in the organization view uncertainty in the industry (Allaire and Firsirotu, 1989; Guth, 1976; Jauch and Kraft, 1986). Since balancers are superior performers, analyzers learn primarily from prospectors before taking action, and defenders learn from all other businesses, the high levels of certainty are expected. Likewise, knowledge of competitive actions is not as critical to prospectors as to other businesses since prospectors attempt to move first and define their industries (Miles and Snow, 1986). Since reactors are poorly conceived organizations, it is also expected that they should report high levels of uncertainty.

H3: Strategic uncertainties about competitors, customers, and the environment will be a significant predictor of the generic strategy selected by businesses.

If the second hypothesis is supported and strategy is found to possess a measurable uncertainty component, then it is logical that the generic strategy selected by a business unit is a function of the degree and type of uncertainty perceived by its top managers. Support for this proposition will strengthen the uncertainty-strategy nexus developed in this paper (Allaire and Firsirotu, 1989; Ashmore, 1992).

Methods

The four-digit standard industrial classification (SIC) code was chosen as an appropriate parameter of the industrial environment in which businesses compete (Thomas and Venkatraman, 1988). The industry examined in this study, SIC-5141, is composed of wholesale grocers. This industry was selected because of its historical record of moderate stability.

The model testing procedure necessitates scales to measure the generic strategy construct. Conant et al. (1990) developed an 11-item scale that considers each of the 11 adaptive cycles in the original Miles and Snow (1978) typology. In their initial test of the scale, the mean reliability coefficient of 0.69 paralleled Nunnally's (1978) guideline of 0.70 .

Modifying Conant et al. (1990), the present study considers four strategic domains: 
1 the product/service orientation;

2 competition;

3 the organization; and

4 the approach toward change.

Each domain is examined with an item concerning present focus, one concerning future intentions, and one addressing consumer perceptions. Five responses - one for each strategy - were developed for each of the resultant 12 items. The order of the responses was intentionally varied to eliminate question ordering bias (see Appendix).

Businesses were placed in categories of Miles and Snow's (1978) typology according to a classification scheme also based on the one used by Conant et al. (1990). A business was classified as pursuing the strategy reflected by the highest number of its responses. When there was a tie between the reactor and one or two other strategies, the business was classified as a reactor. When there was a tie between or among non-reactor strategies, the business was classified as an analyzer (see Appendix).

A second set of questions was used to measure strategic uncertainties (see Appendix). Respondents were asked to assess three areas:

1 Uncertainty about competitors. Respondents were asked their perceptions about present and prospective competitor actions. These two items were averaged for each respondent, and then averaged with the other respondents for the business to calculate one overall score (UNCCOM).

2 Uncertainty about customers. Respondents were asked their perceptions about customers' current needs and future needs. These two items were averaged for each respondent, and then averaged with the other respondents for the business to calculate one overall score (UNCCUS).

3 Uncertainty about the environment. Respondents were asked their perceptions about the external environment and changes in the environment. These two items were averaged for each respondent, and then averaged with the other respondents for the business to calculate one overall score (UNCENV).

Three business clusters reflecting high, moderate, and low uncertainties will be forced for each of the three uncertainty measures utilizing the Ward's clustering algorithm. Since Ward's clustering method is most likely to yield clusters of similar sizes, Barney and Hoskisson (1990) suggested that it is appropriate for strategic group research.

The performance constructed was measured through ROA in each of three years from 1990 to 1992. The decision to examine ROA for each year separately and then as a composite was made to overcome some of the problems associated with developing a single performance measure (King, 1983). Since most businesses in the sample were privately held, the respondents provided ROA figures; for public companies, ROA figures were compared to archival data to check for consistency. Revenue figures were also provided by respondents and compared to revenue figures available in archival data (i.e. Ward's Business Directory, 1993).

The instrument consisting of the generic strategy scale, uncertainty and performance items was sent to the top managers of the 428 largest businesses classified as wholesale grocers (Ward's Business Directory, 1993). This sample constitutes all reporting businesses with sales in excess of US\$1,000,000 in 1992. In exchange for their participation in the study, managers were guaranteed anonymity. A list of survey items appears in the Appendix. The present study did not rely solely on top manager perceptions to classify businesses into strategic groups. Based on CEO assessments, Golden (1992) found that 58 percent of organizations he surveyed did not agree with the previously validated accounts of their organization's past strategies. Hence, valid accounts of strategy should emanate from more than one assessment of strategy to ensure validity.

In the present study, top executives were asked to complete one survey, forward a second survey to another top manager and a third to a middle manager. Each survey was to be sealed and returned in separate envelopes. Agreement by two of the three respondents for each business was required to assign a strategy. For example, if according to the categorization scheme two respondents classified their organization as a prospector and one as an analyzer, the prospector strategy was assigned to the business. However, if each respondent suggested a 
different strategy, the business was classified as a reactor.

Results and discussion

Responses were obtained from 147 businesses in the sample. However, ten were eliminated from the analysis as a result of substantial discrepancies in reported performance data and archival data. The remaining 137 businesses were utilized in the study for a response rate of 32 percent. The classification scheme produced 26 defenders, 28 prospectors, 32 analyzers, 17 balancers, and 34 reactors. Several tests were performed to examine the validity of the instrument.

As predicted in the first proposition, balancers were the high performers in the industry while reactors were the low performers. Specifically, defenders, prospectors, and analyzers reported moderate ROAs for each year, whereas reactors reported the lowest in each year, lending support to the first proposition. The greatest discrepancies in performance occurred in the last year of the survey. Results of an analysis of variance (ANOVA) demonstrated that these differences were significant (see Table I). Further, results of a multivariate analysis of variance (MANOVA) demonstrated that strategy was a significant predictor of ROA in each of the three years studied (see Table II). To test the second proposition, means for uncertainty about competitors (UNCCOM), uncertainty about the environment (UNCENV), and uncertainty about customers (UNCCUS) were calculated for each strategic group (see Table III).

Balancers, analyzers, and defenders reported the greatest levels of certainty about competitive action. Balancers and defenders exhibited the greatest amount of certainty about their environments. The defender's certainty emanates from concentration on only one subset of the environment; the mechanistic, bureaucratic structure common to the defender makes it best suited for more stable and certain environments (Dutton, 1982; McCabe, 1990). The balancer's certainty emanates from confidence resulting from superior performance in the past and its ability to develop the unique systems required to analyze and comprehend the environment (Wright et al., 1990). In contrast, prospectors seek new product and market opportunities; hence, they were most uncertain about their environments; the organic, loose structure common to the prospector makes it best suited for turbulent, uncertain environments (Bourgeois et al., 1978; McCabe, 1990). Analyzers exhibited moderate environmental uncertainty, perhaps reflecting their moderate involvement in new and changing domains (Miles and Snow, 1986).

Businesses in all viable strategic groups reported relatively high degrees of certainty about their customer bases. Reactors reported the greatest uncertainty about their customers. Hence, the second proposition was strongly supported. This finding also supports Daft and Weick's (1984) contention that reactors view their environment as unanalyzable.

The third proposition was largely, but not completely supported. The cluster algorithm produced three sets of clusters for each variable - UNCCOMC3 (clusters of 68, 42 and 27), UNCCUSC3 (clusters of 40, 55 and 42), and UNCENVC3 (clusters of 40, 42 and 55). The discriminant analysis tested the ability of strategic uncertainty clusters to predict generic strategy. Results indicate that, while uncertainty about customers and uncertainty about the environment were significant predictors, uncertainty about competitors was not (see Table IV). The discriminant function was able to correctly predict the strategic membership of 49.64 percent of the businesses based on perceived uncertainties. Press's Q (see Hair et al., 1992) was calculated to be 75.2 , suggesting that the items were strong predictors of strategic group membership (see Table V).

Conclusions and directions for future research

This study lends support to the notion that strategy formulation is to some extent a response to key perceived uncertainties about strategic factors. Following this logic, viable strategic options may be limited more by the cognitive and perceptual abilities of an organization's managers than by objective measures of resources, industry competitiveness, and the like. Hence, the premise that strategy must "fit" with organizational or environmental factors to be effective may be incomplete. Perhaps a strategy should also fit with the psychological characteristics and constraints of the managers responsible for its formulation and implementation. Miles and Snow (1978) addressed this issue of managerial constraints and characteristics in some detail, emphasizing managers' perceptions of uncertainty. However, the interviews collected by Miles and Snow (1978) 
tended not to follow the relationships they predicted. Specifically, organizations were not structured to reflect the actual relations that existed between environments and themselves.

Miles and Snow (1978) believed that this discrepancy resulted from the inability to equally weight managers' perceptions of the environment. To fully understand a company's actions or responses to environmental change, the researcher had to probe the patterns of power of the managers and their ability to influence. The path taken by a manager to the top was critical in explaining his/her reactions. A background in production and operations led to distinctly different reactions to environmental change from a background in marketing, for example. This past path was also important in understanding managers' choices of subordinates.

Miles and Snow (1978) explored another issue that remains relevant to the present study. Specifically, managers had trouble perceiving the environment outside of their firm's place in the industry. Many of the managers Miles and Snow (1978) interviewed wanted to express their perceptions in much more detail than was called for in the interview. Their perceptions were constantly evolving, so that perceptions may vary substantially from year to year. In addition, managers' perceptions were tied very closely to their individual organizations.

The present study's finding that competitive uncertainty was not a predictor of generic strategy could support Miles and Snow's findings (1978) regarding managers' backgrounds. The wholesale grocer industry utilizes external salespeople and delivery persons who visit each customer on a regular basis. Competitor information is readily available to these boundary spanners from customers who are comparing prices, quality, and service of suppliers. Over time, these wholesale grocers develop enough information on their competitors to utilize in strategy development, but they are limited in their reaction by their own firm's capabilities. They react to environmental change, therefore, based on their customers' needs and how they can best meet them within the confines of their limited knowledge base, developed through their path to power and influence.

Three opportunities for future research have been identified. First, why do some businesses develop the ability to adopt prospector and defender (i.e. combine strategies) types simultaneously and effectively while others do not? What is the role of uncertainty in the phenomenon? Whereas strategic management researchers are often criticized for their inability to identify clear management applications (Dacko and Sudharshan, 1996; Gopinath and Hoffman, 1995), this avenue of inquiry could lead to the development of prescriptive research aimed at improving top management's ability to formulate effective strategies.

Future research should consider the wide array of analytical and behavioral attributes associated with the balancer strategy. The factors could include the stages in the industry and organizational life cycles, attributes or background of the CEO, the quality of human resources, or the consistency of the strategy over time. Hence, the empirical support in this paper for the "fifth strategy type" should be followed by a more thorough depiction of the type of organization capable of successfully adapting the balancer strategy.

Second, most empirical investigations concerning strategy typologies have focused on one industry. This study was no exception. Thus, the strategy-performance relationship may be heavily moderated by industry. For example, it is possible that in stable, mature industries, "pure" defender strategies may yield the highest performance levels. However, in dynamic, volatile industries, combination strategies may serve as a more effective means of adapting to unpredictable environmental changes.

Finally, the present study suggests that uncertainty influences strategy development, but little is known about the process by which managers respond to uncertainty in formulating strategy. Bourgeois (1985) found that consensus on perceived environmental uncertainty can actually lead to poor performance. Although Milliken (1987) suggested that organizations tend to increase environmental scanning and forecasting when uncertainty is high, perhaps some organizations do not seek to reduce uncertainty and instead formulate strategies to cope with the constraints. The existing research is limited and somewhat contradictory (Eisenhardt, 1989; Fredrickson, 1984; Fredrickson and laquinto, 1989; Fredrickson and Mitchell, 1984; Judge and Miller, 1991).

References

1. Allaire, Y. and Firsirotu, M.E. (1989), "Coping with strategic uncertainty", Sloan Management Review, Spring, pp. 7-16. 
2. Andrews, K. (1971), The Concept of Corporate Strategy, Dow Jones, Homewood, IL.

3. Ansoff, H.I. (1965), Corporate Strategy: An Analytical Approach to Business Policy for Growth and Expansion, McGraw-Hill, New York, NY.

4. Ashmore, G.M. (1992), "Better information means better quality", Journal of Business Strategy, Vol. 13 No. 3, pp. 57-60.

5. Barney, J.B. (1986), "Types of competition and the theory of strategy: toward an integrative framework", Academy of Management Review, Vol. 11, pp. 91-8.

6. Barney, J.B. and Hoskisson, R.E. (1990), "Strategic groups: untested assertions and research proposals", Managerial and Decision Economics, Vol. 11, pp. 187-98.

7. Bourgeois, L.J. (1985), "Strategic goals, perceived uncertainty, and economic performance", Academy of Management Journal, Vol. 28, pp. 548-73.

8. Bourgeois, L.J., McAllister, D.W. and Mitchell, T.R. (1978), "The effects of different organizational environments upon decisions about organizational structure", Academy of Management Journal, Vol. 21, pp. 508-14.

9. Burgelman, R.A. (1983), "A model of the interaction of strategic behavior, corporate context, and the concept of strategy", Academy of Management Review, Vol. 7, pp. 61-70.

10. Buzzell, R.D. and Gale, B.T. (1987), The PIMS Principles, Free Press, New York, NY.

11. Child, J.S. (1972), "Organizational structure, environment, and performance", Sociology,Vol. 6, pp. 1-22.

12. Conant, J.S., Mokwa, M.P. and Varadarajan, P.R. (1990), "Strategic types, distinctive marketing competencies and organizational performance: a multiple measures-based study", Strategic Management Journal, Vol. 11, pp. 365-83.

13. Covin, J.G. (1991), "Entrepreneurial versus conservative firms: a comparison of strategies and performance," Journal of Management Studies, Vol. 28 No. 5, pp. 439-62.

14. Dacko, S.G. and Sudharshan, D. (1996), "Managers will find academic journals helpful", Marketing News, Vol. 30 No. 21, p. 10.

15. Daft, R.L. and Weick, K.E. (1984), "Toward a model of organizations as interpretation systems", Academy of Management Review, Vol. 9 No. 2, pp. 284-95.

16. Dess, G.G. and Davis, P.S. (1984), "Porter's generic strategies as determinants of strategic group membership and performance", Academy of Management Journal, Vol. 26, pp. 467-88.

17. Dutton, J.E. (1982), "The processing of crisis and non-crisis strategic issues: a situationalist perspective", working paper, New York University, NY.

18. Eisenhardt, K.M. (1989), "Making fast strategic decisions in high velocity environments", Academy of Management Journal, Vol. 32, pp. 543-76.

19. Fredrickson, J.W. (1984), "The comprehensiveness of strategic decision processes: extension, observations, future directions", Academy of Management Journal, Vol. 27, pp. 445-66.

20. Fredrickson, J.W. and laquinto, A.L. (1989), "Inertia and creeping rationality in strategic decision processes", Academy of Management Journal, Vol. 32, pp. 543-76.

21. Fredrickson, J.W. and Mitchell, T.R. (1984), "Strategic decision processes: comprehensiveness and performance in an industry with an unstable environment", Academy of Management Journal, Vol. 27, pp. 399-423. 22. Golden, B.R. (1992), "The past is the past - or is it? The use of retrospective accounts as indicators of past strategy", Academy of Management Journal, Vol. 35, pp. 848-60.

23. Gopinath, C. and Hoffman, R.C. 1995, "The relevance of strategy research: practitioner and academic viewpoints", Journal of Management Studies, Vol. 32, pp. 575-94.

24. Guth, W. (1976), "Toward a social system theory of corporate strategy", Journal of Business, Vol. 49, pp. 374-88.

25. Hair, J.F. Jr, Anderson, R.E., Tatham, R.L. and Black, W.C. (1992), Multivariate Data Analysis (3rd ed.), Macmillan, New York, NY.

26. Hambrick, D.C. (1979), "Environmental scanning, organizational strategy, and executives' roles: a study in 
mature industries", unpublished Doctoral dissertation, Pennsylvania State University, PA.

27. Hambrick, D.C. (1981), "Strategic awareness within top management teams", Strategic Management Journal, Vol. 2, pp. 263-79.

28. Hambrick, D.C. (1982), "Environmental scanning and organizational strategy", Strategic Management Journal, Vol. 3, pp. 159-74.

29. Hambrick, D.C. (1983), "Some tests of the effectiveness and functional attributes of Miles and Snow's strategic types", Academy of Management Journal, Vol. 26, pp. 5-26.

30. Hamilton, R.T. and Shergill, G.S. (1992), "The relationship between strategy-structure fit and financial performance in New Zealand: evidence of generality and validity with enhanced controls", Journal of Management Studies, Vol. 29 No. 1, pp. 95-113.

31. Hart, S.L. (1992), "An integrative framework for strategy-making processes", Academy of Management Review, Vol. 17, pp. 327-51.

32. Hawes, J.M. and Crittendon, W.F. (1984), "A taxonomy of competitive retailing strategies", Strategic Management, Vol. 5, pp. 275-87.

33. Herbert, T.T. and Deresky, H. (1987), "Generic strategies: an empirical investigation of typology validity and strategy content", Strategic Management Journal, Vol. 8, pp. 135-47.

34. Hiam, A. (1993), "Strategic planning unbound", Journal of Business Strategy, Vol. 14 No. 2, pp. 46-52.

35. Hill, C.W.L. (1988), "Differentiation versus low cost or differentiation and low cost: a contingency framework", Academy of Management Review, Vol. 13, pp. 401-12.

36. Hurst, D., Rush, J. and White, R. (1989), "Top management teams and organization renewal", Strategic Management Journal, Vol. 10, pp. 87-105.

37. Jauch, L.R. and Kraft, K.L. (1986), "Strategic management of uncertainty", Academy of Management Review, Vol. 11, pp. 777-90.

38. Jones, G.R. and Butler, J.E. (1988), "Costs, revenue, and business-level strategy", Academy of Management Review, Vol. 13, pp. 202-13.

39. Judge, W.Q. and Miller, A. (1991), "Antecedents and outcomes of decision speed in different environmental contexts", Academy of Management Journal, Vol. 34, pp. 449-63.

40. King, W.R. (1983), "Evaluating strategic planning systems", Strategic Management Journal, Vol. 4, pp. 263-77. 41. Kotha, S., Dunbar, R.L.M. and Birf, A. (1995), "Strategic action generation: a comparison of emphasis placed on generic competitive methods by US and Japanese managers", Strategic Management Journal, Vol. 16, pp. 195-220.

42. Lawless, M.W. and Finch, L.K. (1989), "Choice and determinism: a test of Hrebiniak and Joyce's framework on strategy-environment fit", Strategic Management Journal, Vol. 10, pp. 351-65.

43. Lemak, D.J. and Arunthanes, W. (1997), "Global business strategy: a contingency approach", Multinational Business Review, Vol. 5 No. 1, pp. 26-37.

44. Luo, Y. (1997), "Performance implications of international strategy: an empirical study of foreign-invested enterprises in China", Group \&Organization Management, Vol. 22 No. 1, pp. 87-116.

45. McCabe, D.L. (1990), "The assessment of perceived environmental uncertainty and economic performance", Human Relations, Vol. 43, pp. 1203-18.

46. McDaniel, S.W. and Kolari, J.W. (1987), "Marketing strategy implications of the Miles and Snow strategic typology", Journal of Marketing, Vol. 51 No. 4, pp. 19-30.

47. McKee, D.O., Varadarajan, P.R. and Pride, W.M. (1989), "Stategic adaptability and firm performance: a marketcontingent perspective", Journal of Marketing, Vol. 53, pp. 21-35.

48. Meyer, A.D. (1982), "Adapting to environmental jolts", Administrative Science Quarterly, Vol. 27, pp. 515-37. 49. Miles, R.E. and Snow, C.C. (1978), Organizational Strategy, Structure, and Process, West, New York, NY. 50. Miles, R.E. and Snow, C.C. (1986), "Organizations: new concepts for new forms", California Management Review, Vol. 18 No. 3, pp. 62-73. 
51. Milliken, F.J. (1987), "Three types of perceived environmental uncertainty: state, effect, and response uncertainty", Academy of Management Review, Vol. 12, pp. 133-43.

52. Mintzberg, H. and Waters, J.A. (1985), "Of strategies, deliberate and emergent", Strategic Management Journal, Vol. 6, pp. 257-72.

53. Murray, A.I. (1988), "A contingency view of Porter's 'generic strategies"', Academy of Management Review, Vol. 31, pp. 390-400.

54. Namiki, N. (1989), "Miles and Snow's typology of strategy, perceived environmental uncertainty, and organizational performance", Akron Business and Economic Review, Vol. 20 No. 2, pp. 72-88.

55. Neilsen, A. (1992), "A new metaphor for strategic fit: all that jazz", Leadership \&Organization Development Journal, Vol. 13 No. 5, pp. 3-6.

56. Nichol, R.L. (1992), "Get middle managers involved in the planning process", Journal of Business Strategy, Vol. 13 No. 3, p. 2.

57. Nunnally, J. (1978), Psychometric Theory, McGraw-Hill, New York, NY.

58. Parnell, J.A., Crandall, W.R. and Wright, P. (1993), "The generic strategy-performance relationship: an empirical investigation of the balancer strategy", Proceedings of the 1993 Midwest Academy of Management Meeting, Indianapolis, IN, pp. 65-71.

59. Porter, M.E. (1980), Competitive Strategy, Free Press, New York, NY.

60. Ruekert, R.W. and Walker, O.C. Jr (1987), "Interactions between marketing and R\&D departments in implementing different business strategies", Strategic Management Journal, Vol. 8, pp. 233-48.

61. Schendel, D. and Hofer, C. (1979), Strategic Management, Little Brown, Boston, MA.

62. Snow, C.C. and Hrebiniak, L.G. (1980), "Strategy, distinctive competence and organizational performance", Academy of Management Review, Vol. 25, pp. 317-36.

63. Thomas, H. and Venkatraman, N. (1988), "Research on strategic groups: progress and proposals", Journal of Management Studies, Vol. 25, pp. 527-55.

64. Thompson, J.D. (1967), Organizations in Action, McGraw-Hill, New York, NY.

65. Ward's Business Directory (1993), Ward's Directory of US Private and Public Companies, Gale Research, Washington, DC.

66. White, R.E. (1986), "Generic business strategies, organizational context, and performance: an empirical investigation", Strategic Management Journal, Vol. 7, pp. 217-31.

67. Wooldridge, B. and Floyd, S.W. (1989), "Strategic process effects on consensus", Strategic Management Journal, Vol. 10, pp. 295-302.

68. Wooldridge, B. and Floyd, S.W. (1990), "The strategy process, middle management involvement, and organizational performance", Strategic Management Journal, Vol. 11, pp. 231-41.

69. Wright, P. (1987), "A refinement of Porter's strategies", Strategic Management Journal, Vol. 8, pp. 93-101.

70. Wright, P., Kroll, M., Chan, P. and Hamel, K. (1991a), "Strategic profiles and performance: an empirical test of select key propositions", Journal of the Academy of Marketing Science, Vol. 19, pp. 245-54.

71. Wright, P., Kroll, M., Pringle, C. and Johnson, J. (1990), "Organizational types, conduct, profitability and risk in the semiconductor industry", Journal of Management Systems, Vol. 2 No. 2, pp. 33-48.

72. Wright, P., Kroll, M., Tu, H. and Helms, M. (1991b), "Generic strategies and business performances: an empirical study of the screw machine products industry", British Journal of Management, Vol. 2, pp. 57-65.

73. Zahra, S.A. (1987), "Corporate strategic types, environmental perceptions, managerial philosophies, and goals: an empirical study", Akron Business and Economic Review, Vol. 18 No. 2, pp. 64-77.

Appendix. Strategy items

- 1 Considering our products and services, we:

- Primarily seek to provide the highest quality products and services possible.

- Primarily seek to provide our products and services at the lowest possible price.

- Primarily seek to differentiate our products and services from those of our competitors. 
- Tend to emphasize one or more factors such as quality, price or uniqueness for a while, and later emphasize other factors.

- Primarily seek to provide products and services most consistent with consumer demands.

- 2 In the future, we plan to position our company in the marketplace as:

- One that does the best job meeting consumer demands.

- One that does whatever generates the greatest return at that time.

- One that responds quickly to change.

- One that satisfies the demands of a particular group of consumers exceptionally well.

- One that leads the way in new products and services.

- 3 If asked about our company, most current and prospective customers would:

- Consider us to be an efficient producer of goods and services.

- Consider us to be highly innovative.

- Feel as if we understand them well as customers.

- Stress our ability to do many things well.

- Identify us with no particular area of distinctive competence.

- 4 How does your company view change in the marketplace or our external environment?

- We usually try to initiate change.

- We see change as continuous.

- We don't think much about change.

- We usually try to adapt to change.

- We usually try to resist change.

- 5 Most current and prospective customers probably:

- See our products and services as among the lowest priced available.

- See our products and services to be the most in-tune with customer demands.

- See a very high value in our products and services.

- Consider our products and services to be among the most unique.

- See different attributes in our products and services.

- 6 Relative to our competition, we:

- Generate more than our share of new products and services.

- Develop and provide products and services to the market at a fast pace.

- Do some things well for a while, and then concentrate on other areas.

- Are the most competent marketers in the industry.

- Provide products and services primarily to a well-defined customer group.

- 7 In the future, we primarily plan to:

- Do lots of things, nothing in particular.

- Focus on high innovation.

- Learn more about our customers.

- Improve our efficiencies.

- Improve our ability to meet changes in the environment quickly and effectively.

- 8 Current and prospective customers probably:

- See us as adapting well to the changes in the market.

- Are unclear about the way we modify our products and services over time.

- View our products and services as stable and traditional.

- Appreciate our constant efforts to modify and update our products and services.

- See us as a leader in the industry.

- 9 One of our goals for the future is to offer products and services that:

- Are easily differentiated from those of our competitors. 
- Contribute to profits, regardless of what we sell.

- Are similar to those of our competitors, but at a lower cost.

- Meet specific consumer demands.

- Maximize quality and value for the consumer.

- 10 If you were to ask our present and potential customers, most would say:

- Different things about our organization.

- That we market our products exceptionally well.

- That we are often the first to modify existing products and services and develop new ones.

- That we respond to the needs of our customers very quickly and effectively.

- That we dominate one segment of the market, but are weak in most others.

- 11 Our company concentrates most on:

- Being flexible.

- Different areas that constantly change.

- High efficiency.

- Innovation.

- Understanding our customers.

- 12 We plan to:

- Remain steadfast and consistent, regardless of changes and trends in the marketplace.

- Modify our products and services as necessary in order to meet changes in the marketplace.

- Redefine our industry.

- Make major changes in our strategy as dictated by the marketplace and our competitors.

- Maintain our strategic focus, but continuously make incremental changes in our strategy to address changes in the marketplace.

\section{Illustration}

Caption: Table II; MANOVA: performance by strategy; Table III; Uncertainty means by strategy; Table I; Performance means by strategy; Table IV; Discriminant analysis: univariate R-ratios; Table V; Discriminant analysis: classification results

\section{DETAILS}

Subject: Uncertainty; Competition; Grocery stores; Management

Classification: $\quad$ 9130: Experimental/theoretical; 2310: Planning

Publication title: $\quad$ Management Decision; London

Volume: $\quad 38$

Issue: $\quad 8$

Pages: $\quad 520-530$

Number of pages: $\quad 0$

Publication year: $\quad 2000$

Publication date: $\quad 2000$ 
Publisher:

Emerald Group Publishing Limited

\begin{tabular}{ll}
\hline Place of publication: & London \\
\hline Country of publication: & United Kingdom, London \\
\hline Publication subject: & Business And Economics--Ma nagement \\
\hline ISSN: & 00251747
\end{tabular}

CODEN: $\quad$ MANDA4

Source type: Scholarly Journals

Language of publication: English

Document type: $\quad$ Feature

ProQuest document ID: $\quad 212074386$

Document URL: $\quad$ https://login.proxy181.nclive.org/login?url=https://search.proquest.com/docview/21 2074386 ? accountid $=13153$

Copyright: $\quad$ Copyright MCB UP Limited (MCB) 2000

Last updated: $\quad$ 2014-05-24

Database: ProQuest Central

\section{LINKS}

Check for full text via 360 Link, Request this item from another library, Check Full Text Finder for Full Text

Database copyright $\odot 2019$ ProQuest LLC. All rights reserved.

Terms and Conditions Contact ProQuest 